\title{
RIVER FLOODPLAINS AS HABITAT AND BIO-CORRIDORS FOR DISTRIBUTION OF LAND SNAILS: THEIR PAST AND PRESENT
}

\author{
JITKA HORÁČKOVÁ ${ }^{1,2}$, ŠTĚPÁNKA PODROUŽKOVÁ ${ }^{1}$ \\ AND LUCIE JUŘIČKOVÁ ${ }^{1}$
}

\begin{abstract}
${ }^{1}$ Department of Zoology, Charles University in Prague, Faculty of Science, Viničná 7 , CZ-128 44 Prague 2, e-mails: jitka.horackova@gmail.com, stepanka.podrouzkova@ gmail.com,lucie.jurickova@seznam.cz

${ }^{2}$ Center for Theoretical Study, Charles University in Prague and the Academy of Sciences of the Czech Republic, Jilská 1, CZ-110 00 Prague 1
\end{abstract}

Received: $23^{\text {rd }}$ October 2015, Accepted: $27^{\text {th }}$ November 2015

\begin{abstract}
River floodplains of Czech rivers serve as refugia to woodland or hydrophilous gastropods,in current intensively agriculturally utilised, urbanised and largely fragmented landscape. This habitat often form one of the last refuge and replace the natural habitat of these species. River floodplains also represent linear bio-corridors in landscape and allow gastropods to spread through the landscape in both directions, up and down the stream. We showed based on available fossil mollusc successions that development of the floodplain mollusc fauna took place quite different way in various river floodplains, depending on their specifics and geographical location, because especially the ones situated in the chernozem area of the Czech Republic had very different history in comparison with those in higher altitudes. The species richness and composition of recent floodplain malacofauna arises from historical development of particular area/site and depends also on environmental factors such as an elevation, humidity gradient, vegetation type and its biomass, light conditions of the site and soil reaction. Recently, the invasive plants represent a serious problem for current floodplain ecosystems; species richness and abundances of terrestrial mollusc floodplain assemblages are changing due to their effect. The impact on gastropods is species-specific and was described for the following species: Impatiens glandulifera, Fallopia japonica subsp. japonica, F. sachalinensis, $F$. × bohemica.
\end{abstract}

Key words: terrestrial gastropods, river floodplain, bio-corridor, plant invasions, historic development

\section{INTRODUCTION}

River floodplain can be defined as a flat bottom of the valley with a characteristic biota, formed and influenced by the river stream (Štěrba et al., 2008; Ložek, 2007; 2011). River floodplains are one of the most dynamic ecosystems in Central Europe. They fulfil numerous functions in the landscape and their ecological research is therefore of a long tradition (Gurnell, 1977; Schnitzler et al. 2005), concerning to study of vegetation (Schnitzler, 1994; 
Horáčková J., Podroužková Š., Juřičková L. : River floodplains as habitat and bio-corridors for distribution of land snails: their past and present

Brown et al. 1997). A number of regional studies have been carried out in the area of Central Europe since the second half of the $20^{\text {th }}$ century (e.g. Ložek, 1955; Bába, 1977; Frank, 1984, 1985; Obrdlík et al., 1995; Čejka, 1999; 2003; Čejka et al. 2008; Ilg et al. 2009; Čejka \& Hamerlík, 2009), and part of them were dealed with malacofauna of Czech rivers (e.g. Ložek, 1947; Horsák, 2000; Vašátko et al. 2002; Myšák \& Horáčková, 2011; Horáčková et al. 2011 a,b; 2013a,b,c; 2014a). Some studies were investigated the inundation influence on the river floodplain malacofauna (Ilg et al., 2009) or the function of river as bio-corridor (Myšák \& Horsák, 2011) but the majority of the above mentioned studies is only descriptive and is missing the analysis of the main patterns of the species composition and diversity of floodplain mollusc assemblages in relation to ecological gradients of the environment. A large number of studies dealing with analysis of the main factors of the environment influencing the species diversity and composition of gastropod assemblages in various types of European temporal woodlands have been published (e.g. Wäreborn, 1969; Bishop, 1980; Martin \& Sommer, 2004a; Cameron \& Pokryszko, 2005; Pokryszko \& Cameron, 2005; Hylander et al., 2005). However until now, the fauna of alluvial forests was neglected. Studies on the floodplain forests of the Danube River (Čejka et al., 2008) and the Elbe River including its tributaries (Horáčková et al., 2014b) were published in the last couple of years.

Floodplain forests and riparian vegetation in the Czech river and brook floodplains serve as refugia for woodland and hydrophilous gastropods, because in the current fragmented and extensively human-utilized country are often ones of the last and hardly replaceable natural habitats.

\section{HISTORY OF RIVER FLOODPLAIN FORMATION}

If we are trying to understand the dynamics of river floodplains, we have to analyse them from the point of view of their establishment. Recently, there are 16 strictly river floodplain sites with fossil mollusc successions (Horáčková et al., 2015) within the area of the Czech Republic and Slovakia. They can help to understand the development of floodplain mollusc assemblages in the post-glacial period. The most detailed evidence comes from the wider area of the tributaries of the lower Elbe River and the Ohře River, which will be used as a model study area in the following text.

The obvious starting point for the succession of European rivers floodplains was the last Ice Age. In the prevalently forest-free landscape rivers formed wild streams (Pokorný, 2011) causing strong erosion and transporting inorganic material. In warmer landscapes or during the warmer periods, so called gallery forests formed around the wild streams, for example in the river floodplain of the Slovak part of the Danube River. Apparently, they could have a character of small forests as confirm the presence of a strictly woodland land-snail species climbing on tree trunks of taller trees, Ena montana, in Zlatná u Dunaje (Juřičková et al., 2014). At the beginning of the Holocene, rivers became centres of development and spreading of woodlands through the landscape. The landscape around the rivers started covering by vegetation faster thanks to an amount of nutrients deposited in the river floodplains. Remarkable so called river phenomenon occurred where rivers cut into the hard bedrock with deep canyons creating mosaic of habitats of different orientation and humidity. (Jeník \& Slavíková, 1964; Ložek, 1988). This can be observed in the middle stretches of the Vltava River or the Berounka River in the Krrivoklátsko or in the Bohemian Karst areas.

Agriculture and human settlement concentrated around the rivers especially on nutritious chernozem soils from the Neolithic age. River alluvia were gradually changing as a result of the Neolithic people activity into an agricultural, more or less forest-free landscape (Jiráň \& 
Venclová, 2007-2008; Pleinerová \& Pavlů, 1979; Pleinerová, 1990) prevented by these activites from spreading of woodlands as well as woodland species of gastropods. Forest-free landscape is in some parts of Bohemia also preserved due to very low precipitation and relatively high average temperatures and is naturally supported by the sub-continental climate as confirmed in palaeobotanical surveys from Zaháji on the lower stream of the Ohře River (Pokorný, 2005; Pokorný et al., 2015) or in the palaeomalacological survey of the neighbouring České Středohoří Mts. (Ložek, 1963; 1964a,b; 1976; 2005; Juřičková et al., 2013a). Climate and human agricultural settlements thus resulted in preserving the mosaic of woodlands, wetlands and open landscape in some areas during the whole Holocene as can be seen in the lower stream of the Ohře River and in the České Středohoří Mts. (Juřičková et al., 2013a,b; Pokorný et al., 2015).

The arrival of agriculture caused a kind of return to glacial conditions in that sense that the open landscape deforested by agriculture became a subject to further, intense erosion. Due to the fact that the eroded landscape was before the arrival of agriculture covered by woodland to a large extent, transported soils sedimented as huge alluvial material that became substrate for floodlplain forests. A mosaic of woodland and forest-free areas was formed this way and became typical for the entire area of nutritious soils in the Czech Republic (Ložek, 1964a,b; Pokorný, 2005). Despite the fact it is difficult to confirm this exactly, the up-to-date research of Quaternary sediments in the river floodplains of Czech as well as west-European Rivers suggests that current floodplain forests are younger than Neolithic colonisation and it is related to erosion in landscape caused by the first farmers (Evans, 1993; Lespez et al., 2008; Pišút \& Čejka, 2002; Juřičková et al., 2013a,b). This process is not possible to confirm without detailed survey of fossiliferous sediments, because nowadays floodplain forests give the impression of primeval woodlands. As an example can serve the Myslivna Nature Reserve on the Ohře River protected as an original natural old floodplain forest. However, based on fossil mollusc succession (Juřičková et al., 2013a) and composition of recent malacocoenoses that are missing mainly woodland species of gastropods (Horáčková et al., 2014b) we consider this protected floodplain forest as relatively recent. While there are recently living many woodland snail species in the upper stretches of the Ohře River, almost half of them are missing in the lower stream of the river despite the fact that there are large protected woodland complexes of floodplain forests offering seemingly ideal habitat for the woodland snails. The impact of human settlement and agriculture on floodplain mollusc assemblages of the Ohře River throughout Holocene is indirectly confirmed due to comparison with Mid-Pleistocene interglacial fauna from three sites in Louny area (middle stream of the Ohře River) (Kovanda et al., 2005). There were numerous woodland species occurring on the site during that period, but these species were only rarely or not occurred during the Holocene interglacial. Based on these facts, it is clear that while there were living fully developed mollusc assemblages in river floodplains of an other parts of Europe until the period of woodland climatic optimum (e.g. Limondin-Lozouet \& Preece, 2004), the agricultural chernozem areas of Central Europe probably never contained woodland malacofauna in the postglacial period due to the impact of early human settlement and agriculture.

There was even documented a similar development in the neighbouring area of the České Středohoří Mts. (Juřičková et al., 2013b). Woodlands composed only a part of landscape mosaic together with wetlands and open biotopes. While the reduction in woodland snails is much more obvious in the floodplain forests of the lower Ohře River caused by human activities in the alluvium itself, these impacts become not so evident in a small brook floodplain of the Milešovský potok Brook in the České Středohoří Mts.There was an impoverishment of recent woodland mollusc assemblages caused rather indirectly through 
Horáčková J., Podroužková Š., Juřičková L. : River floodplains as habitat and bio-corridors for distribution of land snails: their past and present

the prevention of their spreading from the surrounding human-colonized and deforested landscape. Nevertheless, wetland fauna was relatively rich here during the mid-Holocene period compared to the recent. It included several relic species of land snails, such as Nesovitrea petronella, Vertigo geyeri a $V$. genesii, gradually disappearing during the Early Holocene and are completely extinct nowadays. In the Úštěcký potok brook floodplain (Horáčková et al., 2013c) in the eastern part of the České Středohoří Mts., we recorded relatively poor woodland fauna of the Early Holocene enriched by numerous wetland and aquatic mollusc species, gradually changing into rich fauna of woodlands, open biotopes and wetlands during Atlantic period. At the end of the sub-Boreal period the woodland fauna suddenly disappeared from this site and the entire habitat became more acidic and oligotrophic leading to the extinction of majority of woodland snails. Similarly, this development leading from rich forest land snail assemblages to a recent poor malacoenoses was described in the nearby Polomené hory Mts. thick-bedded sandstones area (Ložek, 1998; 2003).

As shown in this review, the development of river and brook floodplains and their biota took place in various ways in different geographical parts of the lower Elbe River and its tributaries in the Czech Republic. It is evident that a current state of recent malacofauna and the overall biota in particular sites is closely related to postglacial development of areas studied and it is necessary to consider it during an actual ecological researches.

\section{RIVER FLOODPLAINS AS LINEAR BIO-CORRIDORS IN LANDSCAPE}

Not every linear element in the landscape necessarily fulfils the function of a bio-corridor for land snails. While road verges that could be considered to be a brilliant way for spreading of synanthropic or steppe species through the landscape do not fulfil this function (Juřičková \& Kučera, 2007), the river floodplains do. As an example can serve direct observations of spreading of individual species along streams documented in recent decades on species such as Arianta arbustorum and Urticicola umbrosus through the river floodplain of the Berounka River into Prague in Central Bohemia (Juřičková, 1995) or also the spreading of Merdigera obscura and Fruticicola fruticum along the river floodplain of the Úslava River into Plzeň in Western Bohemia (Juřičková, 1998). Spreading of snail species through the floodplains can be confirmed based on fossil findings, too. While no individuals of the species of Urticicola umbrosus were found in either of the five Holocene fossil mollusc successions in the lower stream of the Ohře River (Juřičková et al., 2013a), this species is nowadays one of the most abundant ones in the river floodplain malacoenoses of the entire stream (Horáčková et al., 2011a).

The floodplain mollusc assemblages have a relatively fast dynamics, hardly comparable with, for example, relatively conservative primeval forest land snail assemblages (Horsák et al., 2006). While species rich floodplain mollusc assemblages with species such as Urticicola umbrosus, Perforatella bidentata, Macrogastra ventricosa and Clausilia pumila formed on the confluence of the Berounka and Elbe Rivers before the flood in 2002 (Juřičková, 1995), only Urticicola umbrosus remained after the flood (Juřičková, unpublished data).

The fast dynamics of the floodplain land snail assemblages can be demonstrated on two floodplain sites in the lower stream of the Elbe River (Tab.1). The land snail assemblages of these sites were sampled using the same methods in four consecutive seasons, always at the same time. Table 1 shows relatively dramatic oscillations in annual occurrence of individual species. 
Table 1: Occurrence of land snails on sites: Roudnice nad Labem - floodplain forest (left) and Nebočadský luh - floodplain forest (right). Both sites were sampled using the standard methods (Horsák et al., 2013a) - the same person was taking the leaf litter sample on the same route in $2005-2008$.

\begin{tabular}{|c|c|c|c|c|c|c|c|c|}
\hline & 2005 & 2006 & 2007 & 2008 & 2005 & 2006 & 2007 & 2008 \\
\hline Acanthinula aculeata & & & & 1 & & & & \\
\hline Alinda biplicata & 104 & 20 & 66 & 26 & & & & \\
\hline Arianta arbustorum & 2 & 1 & 61 & 20 & & 5 & 3 & 4 \\
\hline Carychium minimum & & & 9 & & & 2 & & 6 \\
\hline Carychium tridentatum & & & 3 & & & & & 2 \\
\hline Clausilia pumila & 11 & 8 & 10 & 8 & & & & \\
\hline Cochlicopa lubrica & & 1 & 123 & 52 & 2 & 121 & 55 & 48 \\
\hline Cochlodina laminata & 20 & 9 & 14 & 1 & & & & \\
\hline Fruticicola fruticum & 7 & 5 & 5 & 8 & & 2 & & 1 \\
\hline Helix pomatia & & 1 & 1 & & & & & \\
\hline Monachoides incarnatus & 5 & 10 & 19 & 7 & & & 1 & \\
\hline Nesovitrea hammonis & 4 & 6 & 18 & 26 & & 2 & & \\
\hline Pseudotrichia rubiginosa & & & & & 1 & 11 & 26 & 12 \\
\hline Punctum pygmaeum & & & 2 & & & & & \\
\hline Succinella oblonga & & & & & 2 & 1 & 4 & 1 \\
\hline Succinea putris & 1 & 1 & 3 & 1 & & 28 & 38 & 18 \\
\hline Trochulus hispidus & 20 & 21 & 93 & 46 & 3 & 1 & & 1 \\
\hline Urticicola umbrosus & 3 & & 2 & 13 & & 2 & & 1 \\
\hline Vallonia costata & & & & 3 & & & & 2 \\
\hline Vallonia pulchella & & & & & & 1 & 2 & \\
\hline Vertigo pygmaea & & & & & & 1 & & \\
\hline Zonitoides nitidus & & & 3 & 1 & 9 & 20 & 100 & 27 \\
\hline
\end{tabular}


Horáčková J., Podroužková Š., Juřičková L. : River floodplains as habitat and bio-corridors for distribution of land snails: their past and present

\section{HOW ARE SNAILS SPREADING THROUGH RIVER FLOODPLAINS?}

Considering the fact that terrestrial gastropods are animals with low mobility (e.g. Cameron, 2015) the question arises how are snails spreading through the river floodplains. The dispersion through vertebrates or insects was documented many times before (e.g. Baur \& Bengtsson, 1987; Gittenberger et al., 2006; Wada et al., 2012). Probably, it is the way, how some species spread between particular rivers. A much more common way of spreading is floating of land snails by the rivers and transport together with flood deposits.

Geologically, river drift is defined as inorganic sediment deposited by the river stream. It can be deposited in the cores of meanders where they form so called aggradational levees. From the biological point of view, these are flood accumulations of organic material consisting of vegetation remains, seeds and shells of molluscs, alternatively also living individuals (Figure 1). This organic flood material is washed ashore and sedimented on the other side of meanders (i.e. undercut-slope banks) than the inorganic one (Ložek \& Juřičková, 2012). The accumulation therefore represents sedimented organic material which is not local. Due to the whirling of the water the material thrown on the bank is already separated in various fine fractions.

Fig. 1: Flood deposits of the lower reaches of the Ohře River by Břežany nad Ohří

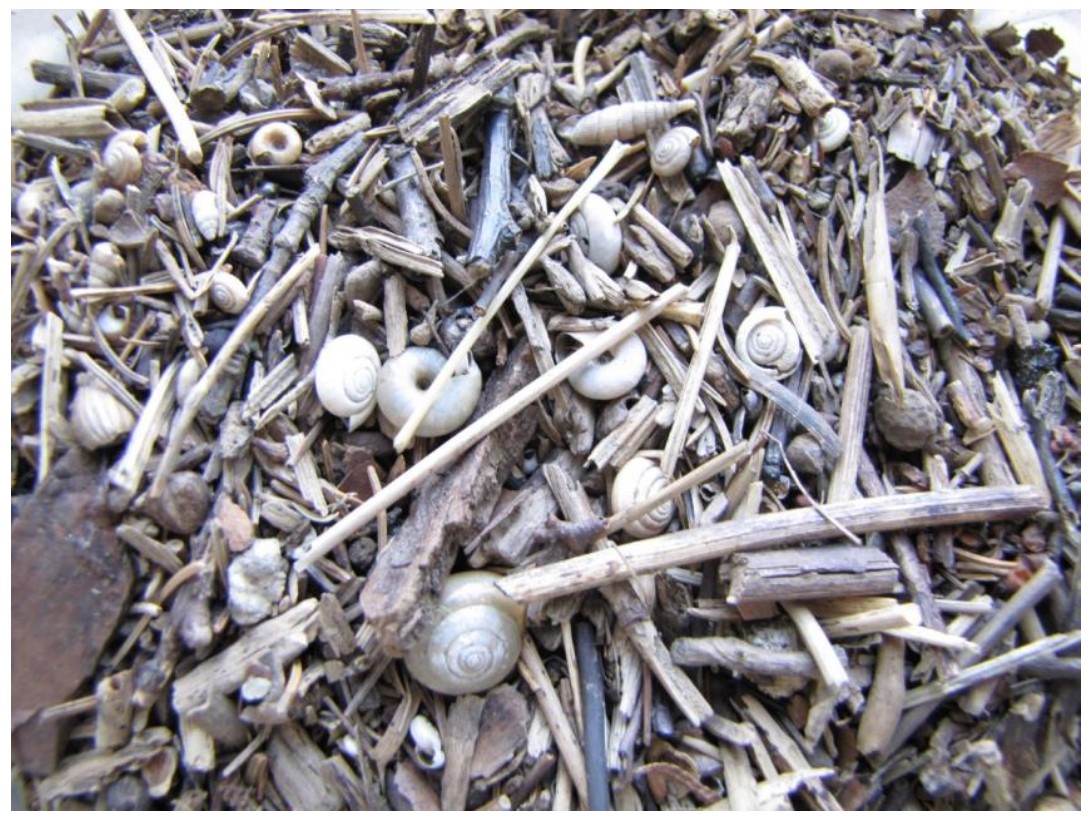

Apart from the fact that snails can successfully spread through flood deposits (Čejka et al., 2015; Podroužková et al. in prep.), the sediments are also of faunistical importance (Ložek \& Juřičková, 2012, Podroužková et. al., in prep.) for allowing of findings of very rare or secretly living snail species that would otherwise remain undiscovered in landscape. As an example can serve the terricolous gastropod Lucilla scintilla. Its vast majority of findings even comes from the fluvial deposits where it lives between grains of sand in the river substrate (Horsák et al., 2009). 


\section{ECOLOGICAL FACTORS INFLUENCING THE COMPOSITION OF FLOODPLAIN SNAIL ASSEMBLAGES}

The composition and the species diversity of the floodplain snail assemblages are related mainly to altitude and moisture gradients (Horáčková et al., 2014b). The influence of altitude on mollusc assemblages has been described many times and is obviously related to winter temperatures (e.g. Horsák \& Cernohorsky, 2008). This effect becomes more evident where the differences in altitudes are considerable, e.g. the malacocoenoses of lowlands are quite varied in comparison with those in montane or alpine vegetation zone. Generally, it is possible to say that with increasing altitude the species diversity of land snails decreases and conversely. In addition, the lower stretches of studied rivers flow through the warm and productive old-settlement region as shown the examples of the lower stretch of the Ohře River (Juřičková et al., 2013a) and elsewhere (Juřičková et al., 2013b; Smolíková \& Ložek, 1978; Ložek, 2005) while the upper streams flow through cold, hilly area with higher average annual precipitation where the human colonisation came much later than in the productive lowlands (Břízová \& Juřičková, 2011). These facts are reflecting in the composition of the floodplain mollusc assemblages and in their species richness which is usually higher in the upper river streams and includes much more woodland and less synanthropic species in comparison with the lower streams of rivers.

Considerable changes in the composition of species richness of the floodplain mollusc assemblages is related to the moisture gradient (Horáčková et al., 2014b). Moisture is often the limiting factor in species composition and abundances of the land snail assemblages because majority of them are susceptible to drying (Cook, 2001) even despite the fact that they fight it either physiologically by estivation in the shell or by the creation of a temporary epiphragma or by mechanical burrowing in the ground (Ložek, 1949). The dependence on moisture is known from the studies dealing with snails of various types of temperate woodlands (Wäreborn, 1969; Martin \& Sommer, 2004a,b) and was described, together with the frequency of floods, as the key factor affecting for example the species composition and diversity of floodplain vegetation (Schnitzler, 1994) or the floodplain mollusc fauna of the Danube River (Čejka et al., 2008). The poorest mollusc assemblages are living usually in the alder carrs (Horáčková et al., 2014b; Čejka et al., 2008) and/or the willow-poplar softwood forests in starting succession phases, representing the moistest and most flood-affected vegetation types in river floodplains. On the contrary, the richest land-snail assemblages are living in the terminal stages of softwood and transitional forests. The species diversity of land snails decreases slightly towards the more dry hardwood forests. Generally, due to a close relationship between molluscs and site moisture, the mollusc assemblages compose of predominantly mesophilic and hydrophilous land snails in the Czech or central European conditions respectively, in contrasts to xerophilous species. This is closely related to the fact that woodland species are more common in Central Europe than species of open habitats (Kerney et al., 1983; Horsák et al., 2013a).

Another gradient proving crucial for gastropods is production of biomass in the herb layer. It probably represents a whole complex of correlated environmental conditions closely related to vegetation composition and structure which is influencing the composition and species richness of mollusc assemblages not only in floodplains. The vegetation structure and species composition control for example micro-climatic site conditions for gastropods (Boycott, 1934; Cameron et al., 1980, Labaune \& Magnin, 2001; Čejka et al., 2008; Dvořáková \& Horsák, 2012 etc.), the amount and quality of food sources (Horsák et al., 2010), sufficiency of suitable shelters (Horsák et al., 2013b) or the amount and quality of leaf litter (Sulikowska-Drozd \& Horsák, 2007; Čejka et al., 2008) all of them directly influencing snail assemblages. 
Horáčková J., Podroužková Š., Juřičková L. : River floodplains as habitat and bio-corridors for distribution of land snails: their past and present

There was numerously observed a positive correlation between the amount of calcium in soil and/or leaf litter and the species richness and composition of mollusc assemblages in various woodland types (Burch, 1955; Wäreborn, 1969; 1970; 1979; Millar \& Waite, 1999; Martin \& Sommer, 2004a; Hylander et al., 2005; Juřičková et al., 2008) and was observed also on open non-forested habitats such as wetlands (Pokryszko, 1993; Horsák \& Hájek, 2003; Horsák 2006) or meadows (Ondina et al., 1998; Dvořáková \& Horsák, 2012). Where the calcium content does not present a limiting factor due to a sufficiency of this element, it is no longer a key factor for mollusc assemblages (Gleich \& Gilbert, 1976; Getz \& Uetz, 1994) as we documented in the case of floodplain forests (Horáčková et al., 2014b). The sufficient amount of calcium utilizable for molluscs in floodlain habitats can be explained by the composition of vegetation, including trees such as Fraxinus excelsior, Acer pseudoplatanus, A. platanoides, Ulmus laevis, U. glabra, sometimes also Tilia cordata, which are often holding high content of citrate form of calcium in their fallen leaves (Čejka et al., 2008; Horáčková et al., 2014b).

\section{IMPACT OF INVASIVE PLANTS ON LAND SNAIL ASSEMBLAGES IN RIVER FLOODPLAINS}

The present state of floodplains in Central Europe is unfortunately closely related with often mass occurrence of invasive plants, primarily of the Fallopia congeners and Impatiens glandulifera, changing the local habitat conditions (Hejda \& Pyšek, 2006; Hejda et al., 2009; Koutika et al., 2011). There is still a limited number of studies dealing with the impact of invasive plants on invertebrate species and/or their assemblages. In several studies, it was clearly established that a decrease in abundances and species richness or changes in species composition in selected groups of arthropods are closely related with plant invasions (Slobodchikoff \& Doyen, 1977; Herrera \& Dudley, 2003; Greenwood et al., 2004; Ernst \& Cappucino, 2005; Topp et al., 2008; Wilkie et al., 2007; etc.). Rather surprisingly, the impact of invasive plants on the abundance, species richness and composition of land snail assemblages has been minimally studied so far, despite the fact that molluscs are non-specific herbivores (Speiser, 2001) and thus form a very suitable model group due to their close relation with the vegetation as well as the habitat. Majority of studies concerning with molluscs in invaded floodplains occur in the last decade (Hedge \& Kriwoken, 2000; Lenz et al., 2003; Kennedy et al., 2005; Kappes et al., 2007; Gerber et al., 2008; Stoll et al., 2012; Ruckli et al., 2013; etc.). It has been confirmed that for example the invasive Tamarix ramosissima decreasess abundances of land snails in the south-west part of the USA (Kennedy et al., 2005). Similar effect was observed in the invasive genus Fallopia in the river bank vegetation in western Germany (Kappes et al., 2007) or on analogous sites in Switzerland (Stoll et al., 2012), while, for example, in temperate mixed woodlands with invasive Impatiens glandulifera in northern Switzerland the abundance and species richness of land snails increased (Ruckli et al., 2013). This short overview shows that the impact is species-specific and can result in a positive or negative influence on mollusc assemblages.

Consequently, when we are studying the impacts of individual invasive species of plants and comparing the level of their impact, it is necessary to study also the impact of congener species. Therefore, Horáčková et al. (2014c) studied the impact of three invasive species of plants of the Fallopia genus ( $F$. japonica, $F$. sachalinensis and their hybrid $F$. × bohemica) and besides also Impatiens glandulifera on the land-snail assemblages in the Czech lower Elbe River basin. 
They confirmed that all studied invasive species of plants impact the species richness and abundance of land snails and showed that this impact is species-specific even in the case of three various species of the Fallopia genus. With the only exception of $F$. $\times$ bohemica, the invasive plants significantly decreased species richness of mollusc assemblages by $16-48 \%$ and the abundances of land snails by $29-90 \%$, with the highest negative impact of F. sachalinensis on their assemblages. Surprisingly, the much more invasive other two Fallopia congeners, did not induce such a vast impact on the mollusc assemblages on the invaded sites. Hybrid $F$. × bohemica even caused a slight increase (by 20\%) of abundances of rare molluscs (such as Macrogastra plicatula and Vertigo pusilla)..Therefore, Horáčková et al. (2014c) showed the invasiveness of a particular invasive plant species does not correspond with its impacts on organisms of the other trophic levels as was also shown in other wider studies, summarising the knowledges on invasiveness of introduced species of plants, vertebrates and invertebrates and their impact on biodiversity (Ricciardi \& Cohen, 2007). When visiting invaded sites, it is immediately obvious that Fallopia species form relatively massive deposits of leaf litter that does not decompose easily (Cornelissen \& Thompson, 1997; Pálková, 2007; Mincheva et al., 2014). A huge layer of poor quality leaf litter is formed there, because there are prevailing slow decomposition by fungi with minimal contribution of microorganisms and other soil bioita. Instead of the fast, mostly microbial decomposition, supported by balanced moisture conditions, good air flow and rich herb layer in the floodplain forests non-invaded by noticed invasive plants. Raw form of humus - the so called mor - is formed on the invaded sites under the thick layer of leaf litter. This form of humus contributes, due to limited processes of mineralisation and humification of organic matter, to the formation of acid soils (Rejšek, 1999; Klimo, 2000) and therefore forms, independently on the geological bedrock, rather acidic environment hardly suitable for the majority of land snails. However, some species of snails prefer habitats with the above mentioned invasive plants and occur there more abundantly than in the surrounding natural vegetation (e.g. Urticicola umbrosus, Succinea putris and others). This phenomenon is probably related to so called climbing behaviour (Boss, 1974; Cowie, 1985; Di Lellis et al., 2012) or utilisation of tall herb plants for climbing up. The climbing used to be explained as an escape mechanism of molluscs from the heated surface of the soil, mainly in the Mediterranean. Nevertheless, this is not the case of floodplain habitats. The question arises why do some species of land snails often climb up in large numbers on the tall invasive and other native plants in river alluvia. Podroužková et al. 2014 explored whether land snails prefer feeding on invasive plants over native plants which could be the reason for their climbing behaviour. Apart from the above mentioned invasive plant species, they also studied Helianthus tuberosus and confirmed that land snails prefer rather senescent plant material to fresh one (Speiser, 2001). The study falsified the hypothesis that molluscs would utilise the selected species of invasive plants as primary sources of food due to the high content of secondary metabolites (Dirzo, 1980) and lignin. Therefore, their climbing behaviour can be explained as a possible escaping strategy from flood or unsuspected fluctuations at the surface of ground water (Rochette \& Dill, 2000; Reid et al., 2013) as well from predators (e.g. Reid et al., 2013; Gerber et al., 2008) or even parasites (McCoy \& Nudds, 1997).

\section{ACKNOWLEDGEMENTS}

The research in river floodplains was partly supported by the Charles University Grant Agency project no. 810213, Grant Agency of the Czech Republic project no. 13-08169S and 
Horáčková J., Podroužková Š., Juřičková L. : River floodplains as habitat and bio-corridors for distribution of land snails: their past and present

Norwegian Financial Mechanism 2009-2014 and the Ministry of Education, Youth and Sports under Project Contract no. MSMT-28477/2014.

\section{REFERENCES}

Bába, K., (1977). Die kontinentalen Schneckenbestände der Eichen-Ulmen-Eschen -Auwäldern (Fraxino pannonicae-Ulmetum pannonicum Soó) in der Ungarischen Tiefebene. Malacologia 16: 51-57.

Baur, B., Bengtsson, J. (1987). Colonizing ability in land snails on Baltic uplift archipelagos. Journal of Biogeography 14, 329-341.

Bishop, M.J., (1980). The Mollusca of acid woodland in the Italian province of Novara. Journal of Conchology 30: 181-188.

Boss, K.J., (1974). Oblomovism in the Mollusca. Transaction of the American Microscopical Society 93: 460-481.

Boycott, A.E., (1934). The habitats of land Mollusca in Britain. Journal of Ecology 22: 138.

Brown, A.G., Harper, D., Peterken, G.F., (1997). European floodplain forests: structure, functioning and management. Global Ecology and Biogeography 6: 169-178.

Břízová, E., Juřičková, L. (2011). Could canopy forests survive agricultural colonization in the Polabí lowland (Czech Republic)? Bulletin of Geosciences 86: 283-300.

Burch, J.B., (1955). Some ecological factors of the soil affecting the distribution andabundance of terrestrial gastropods in eastern Virginia. The Nautilus 69: 62-69.

Cameron, R.A.D., Down, K., Pannett, D.J., (1980). Historical and environmental influences on hedgerow snail faunas. Biological Journal of Linnean Society 13: 75-87.

Cameron, R.A.D., Pokryszko, B.M., (2005). Estimating the species richness and composition of land mollusc communities: problems, consequences and practical advice. Journal of Conchology 38: 529-548.

Cameron, R.D.A. (2015). Speedy snails (and spiedier slugs). World of snails.

Cook, A., (2001). Behavioural ecology: on doing the right thing, in the right place at the right time. In: Barker G.M. (Ed.), The biology of terestrial molluscs (pp. 447-487). Wallingford, CABI Publishing.

Cornelissen, J.H.C., Thompson, K., (1997). Functional leaf attributes predict litter decomposition rate in herbaceous plants. New Phytologist 135: 109-114.

Cowie, R.H., (1985). Microhabitat choice and high temperature tolerance in the land snail Theba pisana (Mollusca: Gastropoda). Journal fo Zoology 207: 201-211.

Čejka, T., (1999). The terrestrial molluscan fauna of the Danubian floodplain (Slovakia). Biologia 54: 489-500.

Čejka, T., (2003). Molluscs (Mollusca). In: Stanová V., Viceníková A. (Eds), Biodiversity of Abrod - state, changes and restoration (pp. 187-190), Bratislava, Daphne - Institute of Applied Ecology.

Čejka, T., Čiliak, M., Šteffek, J. (2015). Molluscan diversity in stream driftwood. Relation to land use and river section. Polish Journal of Ecology DOI: 10.3161/15052249PJE 2015.63.1.011 
Čejka, T., Hamerlík, L. (2009). Land snails as indicators of soil humidity in Danubian woodland (SW Slovakia). Polish Journal of Ecology 57: 741-747.

Čejka, T., Horsák, M., Némethová, D. (2008). The composition and richness of Danubian floodplain forest land snail faunas in relation to forest type and flood frequency. Journal of Molluscan Studies 74: 37-45.

Di Lellis, M.A., Seifan, M., Troschinski, S., Mazzia, C.H., Capowiez, Y., Triebskorn, R., Köhler, H. (2012). Solar radiation stress in climbing snails: behavioural and intrinsic features define the Hsp70 level in natural populations of Xeropicta derbentina (Pulmonata). Cell Stress and Chaperones 17: 717.

Dirzo, R. (1980). Experimental studies on slug-plant interactions: I. The acceptability of thirty plant species to slug Agriolimax caruneae. Journal of Ecology 68: 981-998.

Dvořáková, J., Horsák, M. (2012). Variation of snail assemblages in hay meadows: disentangling the predictive power of abiotic environment and vegetation. Malacologia 55: 151-162.

Ernst, C.M., Cappuccino, N. (2005). The effect of an invasive alien vine, Vincetoxicum rossicum (Asclepiadaceae), on arthropod populations in Ontario old fields. Biological Invasions 7: 417-425.

Evans, J.G. (1993). The influence of human communities on the English chalklands from the Mesolithic to the Iron Age: the molluscan evidence. In: Chambers F.M. (Ed.), Climate change and human impact on the landscap (pp. 147-156), London, Chapman and Hall.

Frank, C. (1984). Aquatische und terrestrische Mollusken der niederösterreichischen Donau Auengebiete und der angrenzenden Biotope. VI. Die Donau von Wien bis zur Staatsgrenze. Teil. 1. Zeitschrift für Angewandte Zoologie 3: 257-303.

Frank, C. (1985). Aquatische und terrestrische Mollusken der niederösterreichischen Donau Auengebiete und der angrenzenden Biotope. VI. Die Donau von Wien bis zur Staatsgrenze. Teil 2. Zeitschrift für Angewandte Zoologie 4: 405-457.

Gerber, E., Krebs, C., Murrell, C., Moretti, M., Rocklin, R., et al. (2008). Exotic invasive knotweeds (Fallopia spp.) negatively affect native plant and invertebrate assemblages in European riparian habitats. Biological Conservation 141: 646-654.

Getz, L.L., Uetz, G.W. (1994). Species diversity of terrestrial snails in the southern Appalachian mountains, U.S.A. Malacological Review 27: 61-74.

Gittenberger, E., Groenenberg, D.S.J., Kokshoorn, B., Preece, R.C. (2006). Molecular trails from hitch- hiking snails. Nature 439, 409.

Gleich, J.G., Gilbert, F.F. (1976). A survey of terrestrial gastropods from central Maine. Canadian Journal of Zoology 54: 620-627.

Greenwood, H., O'Dowd, D.J., Lake, P.S. (2004). Willow (Salix $\times$ rubens) invasion of the riparian zone in south-eastern Australia: reduced abundance and altered composition of terrestrial arthropods. Diversity and Distribution 10: 485-492.

Gurnell, A. (1977). The hydrological and geomorphological sifnificance of forested floodplains. Global Ecology and Biogeography 6: 219-229.

Hedge, P., Kriwoken, L.K., (2000). Evidence for effects of Spartina anglica invasion on benthic macrofauna in Little Swanport estuary, Tasmania. Austral Ecology 25: 150-159.

Hejda, M., Pyšek, P., (2006). What is the impact of Impatiens glandulifera on species diversity of invaded riparian vegetation? Biological Conservation 132: 143-152. 
Horáčková J., Podroužková Š., Juřičková L. : River floodplains as habitat and bio-corridors for distribution of land snails: their past and present

Hejda, M., Pyšek, P., Jarošík, V., (2009). Impact of invasive plants on the species richness, diversity and composition of invaded communities. Journal of Ecology 97: 393-403.

Herrera, A.M., Dudley, T.L., (2003). Reduction of riparian arthropod abundance and diversity as a consequence of giant reed (Arundo donax) invasion. Biological Invasions 5: 167-177.

Horáčková, J., Ložek, V., Juřičková, L. (2011a). Nivní malakofauna řeky Ohře - její minulost a současnost. Malacologica Bohemoslovaca (2011), 10: 51-64

Horáčková, J., Ložek, V. \& Jư̌ičková, L. (2011b). Měkkýši v nivě Milešovského potoka. Malacologica Bohemoslovaca 10: 24-34.

Horáčková, J. \& Juřičková, L., (2013a). Nivní malakofauna Ploučnice (Severní Čechy). [The floodplain mollusc fauna of the Ploučnice River (North Bohemia)]. Malacologica Bohemoslovaca, 12: 40-47.

Horáčková, J., Ložek, V. \& Juřičková, L., (2013b). Malakofauna v nivě Jizery (Severní Čechy). [The mollusc fauna of the Jizera River floodplain (North Bohemia)]. Malacologica Bohemoslovaca, 12: 48-59.

Horáčková, J., Ložek, V., Juřičková, L., (2013c). Malakofauna Úštěckého potoka a její vývoj během holocénu. Malacologica Bohemoslovaca (2013), 12: 26-39.

Horáčková, J., Ložek, V., Beran, L., Juřičková, L., Podroužková, Š., Peterka, J., Čech, M. (2014a). Měkkýši údolí Vltavy Čechy). (Mollusc fauna of the Vltava River Valley (Bohemia). Malacologica Bohemoslovaca 13, 12-105.

Horáčková, J., Horsák, M. \& Juřičková, L. (2014b). Land snail diversity and composition in relation to ecological variations in Central European floodplain forests and history. Community Ecology, 15(1): 44-53.

Horáčková, J., Juřičková, L., Šizling, A.L., Jarošík, V., Pyšek, P. (2014c). Invasiveness Does Not Predict Impact: Response of Native Land Snail Communities to Plant Invasions in Riparian Habitats. PLoS ONE, 9(9): e108296. doi:10.1371/journal.pone.0108296

Horáčková, J., Ložek, V., Juřičková, L. (2015). List of malacologically treated Holocene sites with brief review of palaeomalacological research in the Czech and Slovak Republics. Quaternary International 357: 207-211.

Horsák, M. (2000). Měkkýši (Mollusca) navrhované NPR Oderský luh v CHKO Poodří (Česká republika). Časopis Slezského Muzea Opava (A) 49: 183-187.

Horsák, M. (2006). Mollusc community patterns and species response curves along a mineral richness gradient: a case study in fens. Journal of Biogeography 33: 98-107.

Horsák, M., Novák, J., Novák, M. (2006). Prales NPR Mionší - malakozoologický ráj v Beskydech [Virgin forest of the Mionši National Nature Reserve - a malacological Eden in the Beskydy Mts (South Moravia, Czech Republic)]. Malacologica Bohemoslovaca, 5: 1824. Online serial at <http://mollusca.sav.sk> 12-May-2006.

Horsák, M., Cernohorsky, N. (2008). Mollusc diversity patterns in Central European fens: hotspots and conservation priorities. Journal of Biogeography 35: 1215-1225.

Horsák, M., Hájek, M. (2003). Composition and species richness of mollusc communities in realtion to vegetation and water chemistry in the Western Carpathian spring fens: the poor-rich gradient. Journal of Molluscan Studies 69: 349-357.

Horsák, M., Šteffek, J., Čejka, T., Ložek, V., Juřičková, L. (2009). Occurrence of Lucilla scintilla (R.T. Lowe, 1852) and Lucilla singleyana (Pilsbry, 1890) in the Czech and Slovak 
Republics - with remarks how to distinguish these two non-native minute snails. Malacologica Bohemoslovaca 8: 24-27.

Horsák, M., Chytrý, M., Danihelka, J., Kočí, M., Kubešová, S., Lososová, Z., Otýpková, Z., Tichý, L. (2010). Snail faunas in the Southern Ural forests and their relations to vegetation: an analogue of the Early Holocene assemblages of Central Europe? Journal of Molluscan Studies 76: 1-10.

Horsák, M., Juřičková, L., Picka, J. (2013a). Měkkýši České a Slovenské republiky. (Molluscs of the Czech and Slovak Republics). Nakl. Kabourek, Zlín, 264 pp.

Horsák, M., Chytrý, M., Axmanová, I. (2013b). Exceptionally poor land snail fauna of central Yakutia (NE Russia): climatic and habitat determinants of species richness. Polar Biology 36: 185-191.

Hylander, K., Nilsson, C., Jonssona, B.G., Göthner, T. (2005). Differences in habitat quality explain nestedness in a land snail metacommunity. Oikos 108: 351-361.

Ilg, C., Foeckler, F., Deichner, O., Henle, K. (2009). Extreme flood events favour floodplain mollusc diversity. Hydrobiologia 621: 63-73.

Jeník, J., Slavíková, J. (1964). Střední Vltava a její přehrady z hlediska geobotanického. In: Jeník J. (ed.), Vegetační problémy při budování vodních děl (pp. 67-100). NČSAV, Praha.

Jirán̆, L., Venclová, N. (Eds) (2007-2008). Archeology of the prehistoric Czech 1-8. Archeologický ústav AV ČR v.v.i., Praha.

Juřičková, L. (1995). Měkkýši fauna Velké Prahy a její vývoj pod vlivem urbanizace. Natura Pragensis 12. Český ústav pro ochranu př́rody. 212 pp.

Juřičková, L. (1998). Měkkýši Plzně (Mollusca of Plzeň, West Bohemia, Czech Republic). Sborn. Západočes. Muz. Plzeň, Přir., 96:1-47.

Juřičková, L. \& Kučera, T.: Land snail assemblage patterns along motorways in relation to environmental variables. In: Contributions to Soil Zoology in Central Europe II., Tajovský, K., Schlaghamerský, J. \& Pižl, V. (eds.): (75-7)8. ISB BC AS CR, v.v.i., České Budějovice, 2007. ISBN 978-80-86525-08-2

Juřičková, L., Horsák, M., Cameron, R.A.D., Hylander, K., Míkovcová, A., Hlaváč, J., Rohovec, J. (2008). Land snail distribution patterns within a site: the role of different calcium sources. European Journal of Soil Biology 44: 172-179.

Juřičková, L., Horáčková, J., Ložek, V. \& Horsák, M., (2013a). Impoverishment of recent floodplain forest mollusc fauna in the lower Ohře River (Czech Republic) as a result of prehistoric human impact. Boreas, 42: 932-946.

Juřičková, L., Horáčková, J., Jansová, A., Ložek, V., (2013b). Mollusc succession of a prehistoric settlement area during the Holocene: A case study of the České středohoří Mountains (Czech Republic). The Holocene, 23(12): 1811-1823.

Juřičková, L., Horáčková, J., Ložek, V., (2014). Direct evidence of central European forest refugia during the last glacial period based on mollusc fossils. Quaternary Research, 82: 222-228.

Kappes, H., Lay, R., Topp, W. (2007). Changes in different trophic levels of litter-dwelling macrofauna associated with giant knotweed invasion. Ecosystems 10: 734-744.

Kennedy, T.A., Finlay, J.C., Hobbie, S.E. (2005). Eradication of invasive Tamarix ramosissima along a desert stream increases native fish density. Ecological Applications 15: 2072-2083. 
Horáčková J., Podroužková Š., Juřičková L. : River floodplains as habitat and bio-corridors for distribution of land snails: their past and present

Kerney, M.P., Cameron, R.A.D., Jungbluth, J.H. (1983). Die Landschnecken Nord und Mitteleuropas. Hamburg and Berlin, Verlag Paul Parey, 384 pp.

Klimo, E. (2000). Lesnická pedologie. MZLU Brno, 259 pp.

Koutika, L.S., Rainey, H.J., Dassonville, N. (2011). Impacts of Solidago gigantea, Prunus serotina, Heracleum mantegazzianum and Fallopia japonica invasions on ecosystems. Applied Ecology and Environmental Research 9: 73-83.

Kovanda, J., Horáček, I., Symonová, R. (2005). Pátek, Levousy a Chlumčany - významné fosiliferní středopleistocénní lokality na pravém břehu Ohře mezi Louny a Libochovicemi. Malacologica Bohemoslovaca 3: 149-172.

Labaune, C., Magnin, F. (2001). Land snail communities in Mediterranean upland grassland: the relative importance of four sets of environmental and spatial variables. Journal of Molluscan Studies 67: 463-474.

Lenz, T.I., Moyle-Croft, J.L., Facelli, J.M. (2003). Direct and indirect effects of exotic annual grasses on species composition of a South Australian grassland. Austral Ecology 28: 23-32.

Lespez, L., Clet-Pellerin, M., Limondin-Louzouet, N., Pastre, J.-F., Fontugne, M., Marcigny, C., (2008). Fluvial system evolution and environmental changes during the Holocene in the Mue valley (Western France). Geomorphology 98: 55-70.

Limondin-Lozouet, N., Preece, R.C. (2004). Molluscan successions from the Holocene tufa of St. Germain-le Vasson, Normandy (France) and their biogeographical significance. Journal of Quaternary Science 19(1): 55-71.

Ložek, V. (1947). Měkkýši dolního Povltaví. Časopis Národního muzea 2: 135-148.

Ložek, V. (1949). Studie českých stepí na základě recentních i fosilních měkkýšů. Rozpravy České akademie věd a umění 58/18: 91.

Ložek, V. (1955). Měkkýši lužní reservace u Kozel nad Labem. Ochrana př́rody 10(6): 186. Ložek, V. (1963). Der altholozäne Dauch von Mrsklesy im Böhmischen Mittelgebirge. Antropozoikum 1: 63-74.

Ložek, V. (1964a). Quartärmollusken der Tschechoslowakei. Rozpravy Ústředního ústavu geologického, Praha, 374 pp.

Ložek, V. (1964b). Biostratigraphic research of the important Quaternary profiles of the ČSSR. Zprávy o geologických výzkumech 1: 348-350.

Ložek, V. (1976). Měkkýší fauna potoční nivy pod Kuzovem u Třebívlic. Severočeskou prírodou 7: 1-14.

Ložek, V. (1988). Říční fenomén a přehrady. Vesmír 67: 318-326.

Ložek, V. (1998). Late Bronze Age environmental collapse in the sandstone areas of northern Bohemia. In: Hänsel B. (Ed.), Mensch und Umwelt in der Bronzezeit Europas (pp. 57-60.), Oetker-Voges-Verlag, Kiel.

Ložek, V. (2003). IV. Fosilní měkkýši ve výplních pískovcových převisů a jejich význam pro poznání pravěkého prostředí. In: Svoboda J. (Ed.), Mezolit severních Čech (328 pp), Dolnověstonické studie 9.

Ložek, V. (2005). Holocene malacofauna from Řisuty and its significance for the environmental history of the north-west Bohemian forest steppe area. Severočeskou prírodou 36/37: 11-22. 
Ložek, V. (2007). Zrcadlo minulosti. Česká a slovenská krajina v kvartéru. Praha, Dokořán, 198 pp.

Ložek, V. (2011). Po stopách pravěkých dějů. O silách, které vytvářely naši krajinu. Dokořán, Praha, $181 \mathrm{pp}$.

Ložek, V., Juřičková, L. (2012). Proudové koridory, náplavy a měkkýši. I. Pojem náplav, jeho vymezení a postavení v nivním ekosystému Živa 5: 218-220.II. Co vyčteme z náplavů.. Živa 6: 269-271.

Martin, K., Sommer, M. (2004a). Relationships between land snail assemblage patternsand soil properties in temperate-humid forest ecosystems. Journal of Biogeography 31: 531-545.

Martin, K., Sommer, M. (2004b). Effects of soil properties and land management on the structure of grassland snail assemblages in SW Germany. Pedobiologia 48: 193-203.

McCoy, K., Nudds, T.D. (1997). Interspecific variation in climbing by gastropods: implications for transmission of Parelaphostrongylus tenuis. American Midland Naturalist 137: 320-328.

Millar, A.J., Waite, S. (1999). Molluscs in coppice woodland. Journal of Conchology 36: 2548.

Mincheva, T., Barni, E., Varese, G.C., Brusa, G., Cerabolini, B., et al. (2014). Litter quality, decomposition rates and saprotrophic mycoflora in Fallopia japonica (Houtt.) Ronse Decraene and in adjacent native grassland vegetation. Acta Oecologica 54: 2-35.

Myšák, J. \& Horáčková, J., (2011). Malakofauna údolí Tiché Orlice. [Mollusc fauna of the Tichá Orlice River valley]. Malacologica Bohemoslovaca, 10: 38-44.

Myšák, J., Horsák, M. (2011). Floodplain corridor and slope effects on land mollusc distribution patterns in a riverine valley. Acta Oecologica 37: 146-154.

Obrdlík, P., Falkner, G., Castella, E. (1995). Biodiversity of Gastropoda in European floodplains. Archiv für Hydrobiologie, Suppl. 101: 339-356.

Ondina, P., Mato, S., Hermida, J., Outeiro, A. (1998). Importance of soil exchangeable cations and aluminium content on land snail distribution. Applied Soil Ecology 9: 229-232.

Pálková, K. (2007). Palatabilita druhů, jejich bionomické vlastnosti a rychlost rozkladu detritu. Diplomová práce, Jihočeská univerzita v Českých Budějovicích, České Budějovice, $68 \mathrm{pp}$.

Pišút, P., Čejka, T. (2002). Historical development of floodplain site using Mollusca and cartographic evidence. Ekológia 21/4: 378-396.

Pleinerová, I. (1990). Dva eneolitické dlouhé domy u Března. Památky archeologické 81:266-274.

Pleinerová, I., Pavlů, I. (1979). Březno. Osada z mladší doby kamenné v severozápadních Čechách. Ústí nad Labem, 139 pp.

Podroužková, Š., Janovský, Z., Juřičková, J. \& Horáčková, J. (2014). Do snails eat exotic plant species invading the river floodplains? Journal of Molluscan Studies (2014): 1-8.

Podroužková, Š., ̌̌íhová, D., Juřičková, L. (in prep.). Flood deposits - the storytellers about mollusc fauna: a case study on the Kačák brook (Central Bohemia: Czech Republic).

Pokorný, P. (2005). Role of man in development of Holocene vegetation in Central Bohemia. Preslia 77: 113-127.

Pokorný, P. (2011). Neklidné časy. Kapitoly ze společných dějin přírody a lidí. Dokořán, Praha, 369 pp. 
Horáčková J., Podroužková Š., Juřičková L. : River floodplains as habitat and bio-corridors for distribution of land snails: their past and present

Pokorný, P., Chytrý, M., Juřičková, L., Sádlo, J., Novák, J., Ložek, V. (2015). Mid-Holocene bottleneck for central european dry grasslands: Did steppe eurvive the forest optimum in northern Bohemia, Czech Repulic? The Holocene 25(4), 716-726.

Pokryszko, B.M. (1993). Fen malacocenoses in Dovrefjell (S. Norway). Fauna Norvegica, Ser. A 14: 27-38.

Pokryszko, B.M., Cameron, R.A.D. (2005). Geographical variation in the composition and richness of forest snail faunas in northern Europe. In: Cameron R.A.D., Nekola J.C., Pokryszko B.M., Wells F.E. (Eds), Pattern and proces in land mollusc diversity, (pp. 115132), Records of the Western Australian Museum, Suppl. 68, Perth, Western Australia.

Ricciardi, A., Cohen, J. (2007). The invasiveness of an introduced species does not predict its impact. Biological Invasions 9: 309-315.

Reid, D.G., Claremont, M., Smith, L., Shamoto, M., Glaubrecht, M., Ozawa, T. (2013). Mosaics in the mangroves: allopatric diversification of tree-climbing mudwhelks (Gastropoda: Potamididae: Cerithidea) in the Indo-West Pacific. Biological Journal of the Linnean Society 110: 564-580.

Rejšek, K. (1999). Lesnická pedologie (cvičení). MZLU Brno, 154 s.

Rochette, R., Dill, L.M. (2000). Mortality, behaviour and the effects of predators on the intertidal distribution of littorinid gastropods. Journal of Experimental Marine Biology and Ecology 253: 165-191.

Ruckli, R., Rusterholz, H., Baur, B. (2013). Invasion of Impatiens glandulifera affects terrestrial gastropods by altering microclimate. Acta Oecologica 47: 16-24.

Schnitzler, A. (1994). European alluvial hardwood forests of large floodplains. Journal of Biogeography 14: 97-117.

Schnitzler, A., Hale, B.W., Alsum, E. (2005). Biodiversity of floodplain forests in Europe and eastern North America: a comparative study of the Rhine and Mississippi Valleys. Biodiversity and Conservation 14: 97-114.

Slobodchikoff, C.N., Doyen, J.T. (1977). Effects of Ammophila arenaria on sand dune arthropod communities. Ecology 58: 1171-1175.

Smolíková, L., Ložek, V. (1978). Die nacheiszeitlichen Bodenabfolgen von Poplze und Štětí als Beleg der Boden- und Landschaftsentwicklung im böhmischen Tschernosemgebiet. In: Beitr. zur Quartär und Landschaftsforsch (pp. 531-549). Festschrifte zum 60. Geburgstag von J. Fink. Verlag F. Hirt, Wien.

Speiser, B. (2001). Food and feeding behaviour. In: Barker G. M. (Ed.), The biology of terrestrial molluscs (pp. 259-288), Wallingford, CABI Publishing.

Stoll, P., Gatzsch, K., Rusterholz, R., Baur, B. (2012). Response of plant and gastropod species to knotweed invasion. Basic and Applied Ecology 13: 232-240.

Sulikowska-Drozd, A., Horsák, M. (2007). Woodland mollusc communities along environmental gradients in the East Carpathians. Biologia 62: 201-209.

Štěrba, O. et al. (Ed.) (2008). Řiční krajina a její ekosystémy. Olomouc, Univerzita Palackého v Olomouci, $391 \mathrm{pp}$.

Topp, W., Kappes, H., Rogers, E. (2008). Response of ground-dwelling beetle (Coleoptera) assemblages to giant knotweed (Reynoutria spp.) invasion. Biological Invasions 10: 381390. 
Vašátko, J., Wohlgemuth, E., Horsák, M., (2002). Nivní malakocenózy v povodí dolní Olšavy. Sborník Př́rodovédeckého klubu v Uherském Hradišti 7: 77-88.

Wada, S., Kawakami, K., Chiba, S., (2012). Snails can survive passage throuth a bird's digestive system. Journal of Biogeography 39(1), 69-73. DOI: 10.1111/j.13652699.2011.02559.

Wäreborn, I., (1969). Land molluscs and their environments in an oligotrophic area in southern Sweden. Oikos 20: 461-479.

Wäreborn, I., (1970). Environmental factors influencing the distribution of land molluscs of an oligotrophic area in southern Sweden. Oikos 21: 285-291.

Wäreborn, I., (1979). Reproduction of two species of land snails in relation to calcium salts in foerna layer. Malacologia 18: 177-180.

Wilkie, L., Cassis, G., Gray, M., (2007). The effects on terrestrial arthropod communities of invasion of a coastal heath ecosystem by the exotic weed bitou bush (Chrysanthemoides monilifera ssp. rotundata L.). Biological Invasions 9: 477-498. 